\title{
Paul's call to be a holy man (apostle): In his own words and in other words
}

\author{
John J Pilch ${ }^{1}$ \\ Georgetown University, Washington, DC (USA) \\ Research Associate: Department of New Testament Studies \\ University of Pretoria
}

\begin{abstract}
This brief survey and analysis of the statements made by Paul about his experience of God calling him to be an apostle in Galatians 1:1516; 1 Corinth 15:8-9; 2 Corinth 4:6; and Philippians 3:12 were chiefly conducted from an intentionally limited social science perspective. The article argues that the investigator can gain deeper insights into Paul's statements "in his own words" by submitting them to a social scientific analysis especially drawing upon psychological anthropology and cognitive neuroscience. These social sciences demonstrate that Paul's call was received in an altered state of consciousness experience. As with all such experiences, Paul drew upon the latent discourse of his culture to interpret his vision. It was God's intent and initiative to relate to Paul (Galatians) in an ASC. Paul considered his call experience and commission to be on par with experiences of the Risen Jesus by others (1 Corinthians). Paul also drew upon the full meaning of light imagery in his tradition (his culture's latent discourse) to interpret his call (2 Corinthians). Finally, he was fully aware that his experience took place in an altered state of consciousness (Philippians) which was a wellknown and familiar experience in his culture.
\end{abstract}

\section{INTRODUCTION}

In previous publications, I have described some of Paul's altered states of consciousness experiences. In an article and a book, I reflected upon Luke's three accounts of Paul's call to be an apostle or a holy man: Acts 9:3-19; 22:616; 26:12-18 (see Pilch 2002, [2004]). Drawing upon psychological anthropology and cognitive neuroscience, I demonstrated how Luke narrated that Paul's call took place in the three stages typical of altered states of

\footnotetext{
${ }^{1}$ Prof Dr John J Pilch (Georgetown University, Washington, DC) is a research associate of Prof Dr J G van der Watt, Department of New Testament Studies, Faculty of Theology, University of Pretoria.
} 


\section{Paul's Call to be a holy man (apostle)}

consciousness experiences (ASCs) across cultures. Luke's contemporary readers would immediately understand the event and its significance for Paul.

In another publication, I explored Paul's identity as a holy man by applying etic models of such a person to the interpretation of statements in his letters (Pilch 2003). The models were constructed and proposed by anthropologists who (1) analyzed the process by which a person becomes a holy man/woman across cultures, and who (2) because of the difficulty of proposing a definition of a holy man/woman listed instead eight characteristics of such persons across cultures. One key characteristic of a holy man is the facile ability to access the realm of God in altered states of consciousness. The purpose of such access is to broker information or benefactions from the realm of God to fellow human beings in the human realm.

In this present article, I propose to examine, from a social scientific perspective, Paul's own statements about his call to be a holy man. The social science perspective will help to interpret Paul's own words "in other words". In the authentic letters of Paul (more or less chronologically arranged) his own words about his call are found in GI 1:15-16; 1 Cor 15:8-9; 2 Cor 4:6; and Phlp 3:12 (Stanley 1961:46). In these instances Paul make explicit references to the ASC experience in which he learned more about the God of Israel and about resurrected Jesus. His own words are puzzlingly meager in comparison with Luke's detailed reports which present Paul's experience in one set of "other words". My intention, however, is to submit Paul's statements to a social scientific analysis such as I applied to Luke's words in order to present a view "in still other words".

\section{GALATIANS}

Constructing a chronology for the life and/or letters of Paul is notoriously difficult. The precise years of his birth and date are simply not known. MurphyO'Connor $(1997: 8,31)$ conjectures that Paul was born around 6 BCE and died around CE 67. The call of Paul to be a holy man, an apostle (traditionally but inaccurately called the "conversion" of Paul), quite likely took place around CE 36. Experts propose two dates for the letter to Galatians: an early date (perhaps around CE 49) and a later one, quite likely the Spring, 53 CE (MurphyO'Connor 1997:182). Either date would situate Paul's first mention of his call some thirteen to seventeen years after the actual event.

While contemporary psychologists in general would admit that human beings are indeed capable of maintaining accurate memories of life experiences over long periods of time, there is also a tendency to embellish and reinterpret these memories. This clearly does not seem to be the case with Paul. In his first written report of that life changing event, Paul is surprisingly brief (GI 1:15-17, tr by Stanley 1961:46, modified): 
When he who chose me from my mother's womb and called me by his loving favor, deigned to reveal his Son to me that I might gospel him [among the Israelites dispersed] among the nations, straightway, without seeking instruction from any mere man, without even journeying up to Jerusalem to consult my predecessors, the apostles, I went off into Arabia, returning later to Damascus.

All scholars recognize that by alluding to Isaiah (49:1) and Jeremiah (1:5) in Galatians 1:15, Paul views himself as standing in the prophetic tradition. Therefore, his perceived self-identity is as a communicator of God's will for his contemporaries. Moreover, Paul was convinced that just as his vocation came from God so too did his new understanding of Jesus as Messiah, something he had vigorously denied before. He explicitly expressed that conviction a few verses earlier: “... the gospel that was preached by me is not of human origin. For I did not receive it from a mere mortal, nor was I taught it, but it came through a revelation of Jesus Messiah" (GI 1:11-12). Context (GI 1:15-16) indicates that this latter genitive ("revelation of Jesus Messiah", v 12) should best be interpreted as objective, that is, God revealed to Paul a correct understanding of Jesus to replace his previous mistaken view (Matera 1992:56).

How does God reveal? How did Paul receive this information or new understanding of Jesus? The Greek words translated "revelation/reveal"

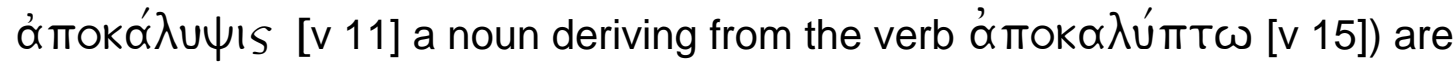
best understood and interpreted in modern, social scientific terms as referring to an altered state of consciousness experience. The Deuteronomic historian is a helpful cultural informant in this regard. A cultural informant is a native who helps a foreigner to understand the alien culture which she or he is visiting. The cultural informant is trustworthy. The informant does not deceive or lie to the foreigner who in turn tries to understand the native experience on its own terms. After gaining such a "native" understanding, the visitor then tries to discover a possible referent in his or her own culture. This is the standard process of building a cultural bridge that is essential for crosscultural communication, understanding, and interpretation.

Now, the Deuteronomic historian writes: "Now the boy Samuel was ministering to the LORD under Eli. And the word of the LORD was rare in those days; there was no frequent vision" (Hebrew: "native" term; "altered state of consciousness experience" is the referent in contemporary psychological anthropology and cognitive neuroscience.

Lexicons, such as Brown-Driver-Briggs, present an ideological interpretation rather than a translation of this word. Since this Hebrew word appears in the title of some prophetic books (e g, Is 1:1; Nah 1:1), the dictionary translates the word as "prophecy." With specific regard to 1 Samuel 


\section{Paul's Call to be a holy man (apostle)}

3:1, $B D B$ renders the word: "divine communication in a vision, oracle, prophecy". From a social scientific perspective, it would be preferable to translate the word simply as "vision". Such a rendition would be literal after the fashion of a formal correspondence translation. The renditions "oracle" or "prophecy" would be literary after the fashion of a dynamic equivalence translation or interpretation. While the context of our particular verse $(1 \mathrm{Sm}$ 3:1) might justify "oracle" or "prophecy", the fact is that the ancients recognized that God routinely communicated with human beings in a variety of altered states of consciousness: visions, dreams, waking dreams, and the like. The object of God's communication could, of course, be many things: advice, information, a threat, a blessing, et cetera. In this instance, the author calls the experience a vision. Moses encountered God in a "marvelous sight" (מפרֵ (Heb) of a bush that was burning but not consumed (Ex 3:3). In this experience, Moses learned God's plan for rescuing the Israelites from Egypt.

How then did Paul gain his new perspective on Jesus Messiah? How ought his statements in Galatians 1:11-12 and 15:17 be understood? Paul quite likely received his insight in an altered state of consciousness, even if not in the dramatic dialogical form presented by Luke in Acts of the Apostles. The insight might have occurred while musing, reflecting, pondering, even critically reviewing what Paul thought he knew and disliked about Jesus. While Paul does not give any details of the revelation in his references, he admits to gaining new insight, to achieving a new understanding because God communicated it to him.

This is not a tradition he heard from a reliable source, memorized, and

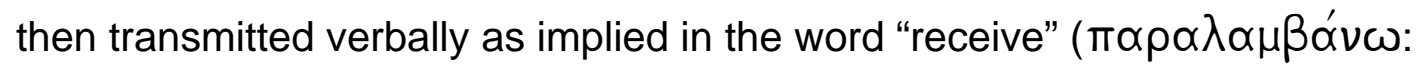
GI 1:12; compare 1 Cor 11:23; 15:3). Neither is it something he learned in the community, the customary context of "taught it" (GI 1:12; compare 1 Cor 14:6, 26; Rm 12:7). He explicitly states that he received it through a revelation, or in social scientific terms, an experience in an altered state of consciousness. Experts have identified at least twenty different levels of awareness or consciousness of which human beings are capable (Pilch 2003). These include dreaming, sleeping, hypnagogic (drowsiness before sleep), hypnopompic (semi-consciousness preceding waking), hyperalert, lethargic, rapture, hysteric, fragmentation, regressive, meditative, trance, reverie, daydreaming, internal scanning, stupor, coma, stored memory, expanded consciousness, and "normal." These states of consciousness actually shade one into another along a continuum with "alert" at one end and deep states (trance) at the other. "Vision" (1 Sm 3:1) could be located between trance and reverie. "Revelation" (GI 1:12, 15), the word Paul uses, is a cultural-ideological interpretation of his altered state of consciousness experience which could plausibly have been a vision, trance or a reverie. Revelation, however, always 
implies God as the source of information or insight. A short while later (GI 2:2), Paul attributes the motivation of his visit to Jerusalem with Titus to a "revelation". In his understanding, the trip was prompted by God in an altered state of consciousness, perhaps meditative, that is, while Paul was reviewing or reflecting upon some aspect of his ministry and his relationship with the Apostles.

In sum, what Paul says in Galatians is that God in an altered state of consciousness provided him with a correct understanding of Jesus as Messiah (GI 1:11-12) and commissioned him just like a prophet to promulgate that (GI 1:15-17).

\subsection{Corinthians}

Murphy-O'Connor dates 1 Corinthians to the Spring of CE 54, thus not very long after the writing of Galatians. This would now be eighteen years after the actual ASC experience. In this letter, Paul makes two references to his call experience. As part of the introduction to a defense of his life, Paul asks four questions. "Am I not free? Am I not an apostle? Have I not seen Jesus our Lord? Are not you my workmanship in the Lord?" (1 Cor 9:1). Each is negatively phrased, and each expects a positive response from the listener. The third question is of interest in our study: "Have I not seen Jesus our Lord?" (1 Cor 9:1). The Greek verb translated "seen" (દópok $\propto$ - perfect tense of opó( $\omega$ ) was commonly used (in the passive form) in early creeds to refer to the experience of the risen Lord in an altered state of consciousness experience (see 1 Cor 15:5, 6, 7, 8; Lk 24:43; Collins 1999:334). Thus Paul is referring to the event he mentions in 1 Cor 15:8 which is his call to be an apostle, a holy man, the Damascus experience. What is remarkable about this high context statement is Paul's plausible assumption that the recipients of this letter are sufficiently familiar with his experience and its details that Paul can mention it so succinctly. This is truly remarkable relative to an event that occurred eighteen years earlier. Whether people believed Paul's experience was genuine or whether they denied it, it seems very clear that they were familiar with it. If they didn't know the details, they at least knew the fact. Paul and his colleagues and admirers must have referred to it on many occasions.

Contemporary readers of Paul's letters need to keep in mind that even if they think that altered states of consciousness experiences are unusual and uncommon in their culture, it was quite common in the ancient Mediterranean world. The anthropologists Erika Bourguignon and her stellar student Felicitas Goodman discovered in their research that various altered states of consciousness were not only normal but institutionalized into religious practices of ninety-six percent of the 486 small societies that they studied in the data base of the Human Relations Area Files at Yale University (Gore 


\section{Paul's Call to be a holy man (apostle)}

1995:4). Ancient Palestine was included in that ethnographic data base. This information helps to appreciate the fact that Paul's boast about "visions and revelations of the Lord" (2 Cor 12:1) is not hyperbole.

Paul's second reference in 1 Corinthians to his experience of the Risen Lord in an altered state of consciousness is also very simple and terse: "Last of all, as to one untimely born, he appeared also to me" (1 Cor 15:8). The Greek word translated "appeared" is the passive form of the Greek verb to see. We just noted above that this form of the word was commonly used in early creedal statements to refer to experiences of the Risen Lord in altered states of consciousness.

Neyrey's (1988:3-24) analysis of 1 Corinthians 15:3-11 helps us to understand the fuller context of Paul's reference to his call. According to Neyrey (1988:14ff), the structure and form of 1 Cor 15:3-11 is tri-partite:

1. A creedal formula of Jesus' death and resurrection (1 Cor $15: 3 b-4)$ is followed by

2. a list of those who saw the risen Jesus (1 Cor 15:5-8) and

3. a personal defense (apologia) for Paul's ministry.

The creedal formula is cast in parallel form:
1. Christ died for our sins
1. He was raised on the third day
2. in accordance with the Scriptures
2. in accordance with the Scriptures
3. and was buried
3. and he appeared to (or was seen by)...

This formula is ancient and emphasizes that everything that happened to Jesus was willed by God ("according to the Scriptures"). That Jesus died and was buried indicates he was a real person who was removed from the realm of the living but was raised by God and seen by many witnesses as having returned to the realm of the living. As Neyrey notes, "death and the undoing of death constitute the core of the kerygma" (Neyrey 1988:15).

The list of those who saw the risen Jesus is presented in similar fashion (1 Cor 15:5-8):

List One:

1. Cephas

2. the Twelve

3. more than 500

\section{List Two:}

1. James

2. all the apostles

3. Paul 
In List One, Cephas (or Simon Peter, see Jn 1:42) was made chief shepherd of the early believers (Jn 21:15-17). The synoptics present only the slightest hint about Peter's "seeing" of the risen Lord (see Lk 24:34). John 21 expands that considerably. The Twelve are, of course, the Apostles called by Jesus (Mk 3:13-19). The "more than 500" have still not been identified. Yet, in two of these instances (Cephas, Jn 21:15-17; and the Apostles, Lk 24:47-49; Ac 1:15-26) the visionaries were commissioned to a task. This is indeed one many functions or purposes of altered states of consciousness experience, namely to learn a new direction in life.

In List Two, James is quite likely the brother of the Lord (Ac 12:17; $15: 13-21 ; \mathrm{GI} 2: 9)$, the second leader of the church at Jerusalem. "All the apostles" are quite likely not the Twelve but rather other gospel proclaimers (Rm 16:7). And Paul is, of course, himself an apostle. "Am I not an apostle? Have I not seen the Lord?" (1 Cor 9:1). The members of this group were also commissioned in their respective altered states of consciousness experiences of the Risen Jesus to a new task and direction in life. While Neyrey claimed that those in list one were commissioned to preach to members of the house of Israel, and those on list two were commissioned to preach to Gentiles, I propose a different perspective on the basis of a work in progress with my colleague, Bruce J Malina ([2006]). Both lists preach to members of the house of Israel. List one concentrates on the house of Israel in places and populations where Israelites predominated. List two is concerned with preachers to members of the house of Israel living among non-Israelite majorities.

Neyrey's general conclusion is still valid. The function of these experiences of the Risen Jesus in altered states of consciousness is to commission the visionaries as preachers. Their audiences would recognize legitimate and trustworthy preachers whose message is based on eye-witness experience of the risen Lord (Neyrey 1988:17).

The third section (1 Cor 15:8-11), Paul's personal defense for his ministry, is rooted in his vision of the Risen Lord Jesus. He uses some common and effective cultural strategies to make his point. To begin with, he places his altered state of consciousness experience on par with those of others commissioned leaders. Then for those who still might not be willing to deal with his claim, Paul first seeks to make himself indispensable. This is a common, Middle Eastern cultural strategy (Malina 1993:126-129). "Last of all" (v 8) doesn't mean that after Paul no one else saw the Risen Lord Jesus in an altered states of consciousness experience. Rather, it means Paul is the most

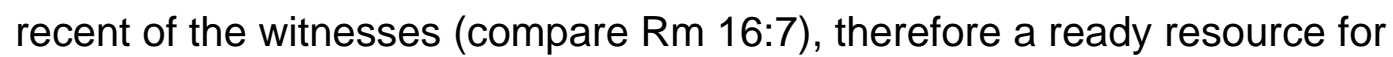
newer members of the community. To deny his very recent experience would be to remove a basic resource in the chain of witnesses. 


\section{Paul's Call to be a holy man (apostle)}

A second cultural strategy implicit in his defense is the claim that his status and function result from "the grace of God" which was "not in vain" in him (v 10). While some may want to challenge or deny this, Paul can point to the fact that James (the brother of the Lord), Cephas, and John (the son of Zebedee) extended the "right hand of fellowship" to him, that is, as social superiors, they acceded to Paul, calling off any hostility and accepting Paul as a fellow apostle (Esler 1998:133). And what prompted such acceptance? "They perceived the grace that was given to me" (GI 2:9). Succinct as Paul's statements may be, it is clear that his experience of the risen Lord Jesus in an altered state of consciousness was not only foundational and formative in his personal life but persuasive to the leaders among the early believers.

\subsection{Corinthians}

Scholars date 2 Corinthians either in 54 (the fall, Lambrecht 1999:6) or in 55 (spring, Murphy-O'Connor 1996:308). Now we are nineteen years removed from Paul's actual experience, but as we shall see, it remains strong and normative in his life. At the same time, since he gives such few details we must conclude that his audience was very familiar with the event and could fill in the details which we, of course, would love to know. Whether one argues for the integrity of 2 Corinthians (Lambrecht 1999:7-9) or defends its composite nature (Murphy-O'Connor 1996:254-256, two letters: "A," and "B"), the verse in which Paul refers to his call to be an apostle received in an altered state of consciousness experience ( 2 Cor $4: 6$ ) is located in that segment that begins in 2 Cor 2:14 and extends to 2 Cor 7:4 (Lambrecht 1996:11). Following upon the body-opening of the letter, this lengthy textsegment presents Paul's defense of his status as an authentic apostle. It is clearly a response to attacks by intruders in Corinth who presented themselves as far superior to Paul in comparison with him.

Lambrecht identifies a concentric pattern in the first section this textsegment (2 Cor 2:14-4:6) that explains its threefold division:

A: 2 Cor 4:14-3:6 - apologetic and polemic in tone: Paul (and his co-workers) defend legitimate apostolic status against opposition from intruders

B: 2 Cor 3:7-18 - contrast between ministry in the Old and New Covenants.

$A^{1}: 2$ Cor 4:1-6 - apologetic and polemic in tone: responding to opposition, Paul speaks about the apostle and his way of life. 
Similarities in vocabulary and thematic content strengthen the link between sections $A$ and $A^{1}$. The middle section, $B$, is significantly different.

The verse in which Paul refers to his call to be an apostle reads: "For it is the God who said, "Let light shine out of the darkness," who has shone in our hearts to give the light of the knowledge of the glory of God in the face of Christ" (RSV), or as Lambrecht translates it: "Because the God who had said "Let light shine out of the darkness" is he who caused light to shine in our hearts [to effect] the illuminating knowledge of the divine glory in the face of Christ" (2 Cor 4:6). Stanley (1961:48) correctly observes that the verse is "overcharged with expression drawn from the metaphor of light." There is a reason for that, and it is not purely theological.

The word "glory" (Greek $\delta o ́ \xi \alpha$ ) takes up a theme from 2 Cor 3:7-18 (mainly vv 7-11). This segment describes Moses' experience of God in an altered state of consciousness (Ex 34:27-35). In a previous publication, I noted that (Pilch 2002)

\begin{abstract}
[i]n the Israelite tradition, light is the manifestation of God's honor or glory (Is 60:1; 62:1; Lk 2:9), that is, God's very self. The light takes the form of a cloud (Ex 24:15ff) or fire (Dt 5:24) flashing brightly (Ezk 1:4, 27-28; 10:4). From a neurological perspective, the bright color signals a shift in consciousness.
\end{abstract}

It is no surprise then, that Paul's reflection on Moses' [ASC] experience in 2 Cor 3:7-18 would bring to mind his own [ASC] experience of "light" (God's glory) on the road to Damascus to which he refers in 2 Cor 4:6. Indeed, "having this ministry by the mercy of God" (2 Cor 4:1) is a clear reference to his call received in an altered state of consciousness (see GI 1:15).

Scholars suggest two texts to which Paul may be alluding in the phrase "Let light shine out of darkness." One possible allusion is to Gn 1:3: "And God said: 'Let there be light'; and there was light." Another allusion might be to Isaiah 9:2 (LXX): "O people walking in darkness, behold a great light: ye that dwell in the region and shadow of death, a light shall shine upon you." The difference between the texts is that the prophet speaks in Isaiah, while God speaks in Genesis and 2 Corinthians. While Paul may be alluding to both texts, the Genesis allusion might be more probable.

Yet the scholarly tradition of searching for allusions on the basis of word association might be missing the point. As this article has been pointing out, the Bible indicates that God reveals or discloses self in a variety of altered states of consciousness experiences. Contemporary cognitive neuroscientists observe that the perception of light is a visual, neurological signal that the level of consciousness has changed. Though the ancients did not know how 


\section{Paul's Call to be a holy man (apostle)}

the brain works, they did associate light with an experience of God's glory, God's very self. Thus, the intruders in Corinth who have been appealing to Moses' experience (2 Cor 3:7-18) as superior to Paul's would prompt him to deny that. That's the thrust of his argument in these verses. His ASC experience was a real as Moses' and indeed superior to it.

Lambrecht (1999: 66) further claims that Paul's statement that God caused his light "to shine in our hearts" (2 Cor 4:6) might be an echo of his statement in Galatians 1:16 that God revealed "his Son in [rather than "to"] me." This then prompts the discussion to turn to the traditional scholarly debate about whether Paul's experience was purely internal, purely external, or - to cover all bases - perhaps a mixture of both (Lambrecht 1999:69). This debate reflects lack of awareness of ancient, Middle Eastern cultural understanding of the human person (see Malina 2001:68-71). These basically anti-introspective persons (see $1 \mathrm{Sm} \mathrm{16:6)}$ perceived human beings in terms of three zones on the external, physical body symbolically interpreted. The "eyes and heart" (and synonyms in those semantic fields) symbolized the zone of emotion fused thought; the mouth and ears (and synonyms) symbolized the zone of self-expressive speech; and the hands and feet (and synonyms) symbolized the zone of purposeful action. Paul's claim that God let the divine light shine in his heart would connect immediately to his eyes which saw God's glory reflected in the face of the risen Messiah Jesus whom Paul "saw" in his ASC experience on the road to Damascus. The result of this ASC experience was knowledge, a new understanding of God and Messiah Jesus.

Relative to 2 Cor 4:6, MacRae (1968:423) writes: ".... it seems difficult to exclude from 2 Cor 4:6 an allusion to Paul's conversion, but the language of the verse is so unspecific that he seems to have wished to generalize to the level of the Christian experience of conversion. That both a specific echo and a generalization are intended is certainly not impossible." We have previously pointed out that it is inappropriate and incorrect to describe the Damascus experience as a "conversion" (Pilch 2002). Hence Paul would quite likely not be relating his experience to the Christian experience of conversion but could indeed be appealing to his readers' or listeners' "common knowledge" about altered states of consciousness experiences as God's chosen medium for communicating with human beings whether Moses, Paul, or anyone else.

Some time later in 2 Corinthians, Paul makes a brief reference to personal "visions and revelations of the Lord" (2 Cor 12:1). He then continues to describe sky journeys that he undertook in altered states of consciousness experience. I have explored and explained this concept in a study of Acts of the Apostles (Pilch 2004). Briefly stated, one function of altered states of consciousness experiences is to allow the visionary to make journeys to the 
realm of God while keeping both feet firmly planted on the ground. Of interest to us at the moment regarding Paul's brief statement in 2 Cor 12:1 is that he makes it so succinctly. This is normal in a high context document of this nature which informs the modern reader that contemporaries of Paul were quite familiar with his topic and reference. They needed no further elucidation to understand what he was talking about or where he went. We do. They were familiar with altered states of consciousness experiences, the functions they served, and they readily understood what a visionary such a Paul was communicating. We in general are not. Not only did Paul receive his call in an altered states of consciousness experience, but true to the nature of a holy man, Paul continued to have such experiences throughout his life as 2 Cor 12:1 states (see Pilch [2003]).

\section{PHILIPPIANS}

Paul's letter to Philippians is yet another composition of a composite nature. Though some defend its integrity, contemporary scholars distinguish three letters in it. Letter A: Phlp 4:10-20, an expression of indebtedness for a gift, and Letter B: Phlp 1:1-2:1a; 4:4-7, 21-23, should probably be dated around CE 54-57. Letter C: Phlp 3:3-4:1 should probably be dated around CE 57-58 (Byrne NBJC 48:10; Murphy-O'Connor 1997:228). It is in Letter C that scholars detect Paul referring to his call to be an apostle: "Not that I have already attained this [the goal I seek] or am already perfect; but I press on to make it my own, because Christ Jesus has made me his own" (Phlp 3:2; RSV). Stanley's translation (1961:49) offers greater clarity: "Not that I am already arrived at the goal or am as yet perfect; but I am [still] in pursuit in the hope that I may capture, since I was myself captured by Christ Jesus.

Scholars agree that this section (Phlp 3:12-16), Paul's Greek is difficult. Hawthorne (1983:148) among others, highlights the same play on words as does Stanley: "But I kept pressing on to see whether I might apprehend Christ Jesus, inasmuch as I was indeed apprehended by him." Paul uses two forms

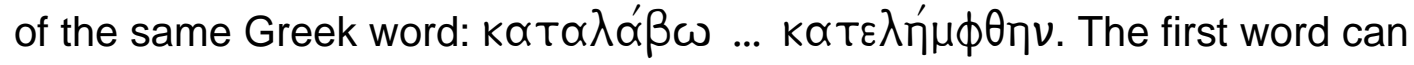
mean "grasp an idea with one's mind," hence, "to understand". This is how Stanley and Hawthorne render it with more precision and greater clarity than the RSV. They also translate the second form of the verb appropriately as "captured" or "apprehended" by Messiah Jesus. In social scientific terms, specialists would say that Paul became as it were "possessed" by the being he saw.

Possession is a complex issue, but Winkelman relying on Goodman and Bourguignon offers some solid guidance through the maze (Winkelman 1999:412-415). The following observations are drawn from Winkelman. The 


\section{Paul's Call to be a holy man (apostle)}

word "possession" itself is often used very loosely to refer to many phenomena: altered states of consciousness, trance, dissociation, spirit domination, displacement of personality, obsession, mental illness, and many other conditions.

Winkelman notes that Bourguignon distinguished possession trances from other types of relationships with spirits in ASC. By possession trance Bourguignon understands "alterations or discontinuity of consciousness, awareness or personality or other aspects of psychology function" that are accounted for by possession. Further, possession is the belief that "a person is changed in some way through the presence in or on him of a spirit entity or power, other than his own personality, soul [or] self." Utilizing these insights without delving unnecessarily into deeper detail, one can plausibly surmise from Paul's statements about being "apprehended", "captured", "snatched" by God that he did indeed feel the presence of God upon himself giving him fresh insight into God and the identity of Messiah Jesus. (See my comments on "snatch" and soul-journeys in Pilch 2004:67.) The ancients would not have the precise knowledge and terminology of modern science, but modern science in this instance seems to contribute to better understanding of what Paul says of his own experience. The "other" words of modern science help to understand Paul "in his own words" and explain him in terms intelligible to contemporary readers.

\section{CONCLUSION}

This brief survey and analysis of the handful of statements Paul made in his letters about his experience of God calling him to be an apostle was conducted chiefly from an intentionally limited social science perspective. The brevity of Paul's statements is typical of high context documents produced by natives of high context cultures. Biblical scholars agree that these four statements in Galatians, 1 and 2 Corinthians, and Philippians do indeed refer to Paul's call to be an apostle. Biblical scholars then tend to explain these statements with information from Acts of the Apostles. It is possible, however, to gain deeper insights into Paul's statements "in his own words" by submitting them to a social scientific analysis drawing especially upon psychological anthropology and cognitive neuroscience. These social sciences demonstrate that Paul's call was definitely received in an altered state of consciousness experience. As with all such experiences, the visionary will draw on the latent discourse of his culture to interpret the vision. Paul certainly does this. It was God's intent and initiative to relate to Paul (GI) in an ASC. Paul considered his call experience and commission to be on par with experiences of the Risen Jesus by others (1 Cor). Paul also drew upon the full meaning of light imagery 
in his tradition to interpret his call (2 Cor). Finally, he was fully aware that his experience took place in an altered state of consciousness (Phlp) which was a well-known and familiar experience in his culture. It is thus possible to explain Paul's words in other words - not only Luke's, but also those of contemporary science.

\section{Works consulted}

Collins, R F 1999. First Corinthians. Collegeville, MN: The Liturgical Press. (Sacra Pagina 7.)

Esler, P F 1998. Galatians. London: Routledge. (New Testament Readings.)

Gore, B 1995. Ecstatic body postures: An alternate reality workbook. Santa Fe, NM: Bear \& Company, Inc.

Hawthorne, G F 1983. Philippians. Waco, TX: Word Books. (Word Biblical Commentary 43.)

MacRae, G W 1968. Anti-Dualist polemic in 2 Cor 4, 6 ? Studia evangelica 1, 420431. Berlin: Akademie-Verlag. (TU 102.)

Malina, B J 1993. Windows on the world of Jesus: Time travel to ancient Judea. Louisville, KY: Westminster John Knox Press.

Malina, B J 2001. The New Testament world: Insights from cultural anthropology. 3rd ed, revised and expanded. Louisville, KY: Westminster John Knox Press.

Malina, B J \& Pilch, J J [2006]. Social Science commentary on the authentic letters of Paul. Minneapolis, MN: Fortress. (Forthcoming).

Matera, F J 1992. Galatians. Collegeville, MN: The Liturgical Press. (Sacra Pagina 9.)

Murphy-O'Connor, J 1997. Paul: A critical life. New York: Oxford University Press. Neyrey, J H 1988. The resurrection stories. Collegeville, MN: The Liturgical Press. Pilch, J J, 2002. Paul's ecstatic trance experience near Damascus in Acts of the Apostles. HTS 58(2), 690-707.

Pilch, J J 2003. Paul's call to be an apostle. Analecta Cracoviensia 35, 221-230

Pilch, J J 2004. Visions and healing in the acts of the apostles: How the early believers experienced God. Collegeville, MN: The Liturgical Press.

Stanley, D M 1961. Christ's resurrection in Pauline soteriology. Rome: Pontifical Biblical Institute.

Winkelman, M 1999. Altered states of consciousness and religious behavior, in Glazier, S D (ed), Anthropology of religion: A handbook, 393-428. Westport, CT: Praeger. 